\title{
Evaluation of a simplified model for estimating energy balance in broilers production housing
}

\author{
Mariano P. Silva', Fernando C. Baêta ${ }^{2}$, Ilda F. F.Tinôco ${ }^{2}$, Sérgio Zolnier² \& Aristides Ribeiro ${ }^{2}$
}

\begin{abstract}
The simulation of poultry house thermal behavior with and without Adiabatic Evaporative Cooling (SRAE) allows the decision makers to evaluate the economical feasibility and the installation costs of a poultry production business. The first step in this research investigation was test the thermal behavior model developed by Gates et al. (1995) for broiler houses in the United States based on the hypothesis that this model, using climatized sheds, as proposed by the authors, could be used under Brazilian conditions. The model is suitable for the proposed objective in the form proposed by Gates et al. (1995) for poultry houses with an elevated mass air flow rate (120.8 $\mathrm{kg} \mathrm{air} \mathrm{s}^{-1}$ or higher). A correction factor referring to a series of heat sources not included in the model, or the inclusion of these sources, is necessary for poultry houses without a high mass air flow.
\end{abstract}

Key-words: mathematical models, chicken production, evaporative cooling

\section{Avaliação de um modelo simplificado para estimativa do balanço de energia em galpões para produção de frangos de corte}

\begin{abstract}
RESUMO
A simulação do comportamento térmico de galpões avícolas com e sem Sistemas de Resfriamento Adiabáticos Evaporativos (SRAE) permite aos tomadores de decisão avaliarem a viabilidade econômica e os custos da instalação de um empreendimento na avicultura de corte. Para operacionalização desta investigação, o primeiro passo foi a execução do teste do modelo de comportamento térmico desenvolvido por Gates et al. (1995) para galpões avícolas nos Estados Unidos, com base na hipótese de que este modelo, utilizando-se galpões climatizados, como sugerido pelos autores, possa ser usado em condições brasileiras. O modelo se mostrou adequado para o objetivo previsto, na forma indicada por Gates et al. (1995) para galpões com vazão mássica do ar elevada, (120,8 kg de ar por segundo ou maior). É necessário um fator de correção referente a uma série de fontes de calor desprezada pelo modelo para galpões sem uma grande vazão mássica, ou a inclusão dessas fontes.
\end{abstract}

Palavras-chave: modelo matemático, produção avícola, resfriamento evaporativos

Graduate student in Agricultural Engineers, Universidade Federal de Viçosa (CNPq scholarship), Rua Pe. Anchieta 29 apt 02. Fone: (31) $9125-9108$. E-mail: mariano@mariano.pro.br

2 DEA/UFV, Campus Universitário, CEP 36570-000, Viçosa, MG. Fone: (31) 3899-1884. E-mail: iftinoco@ufv.br 


\section{INTRODUCTION}

Brazil has the world's largest poultry industry, and also the lowest production costs. In a tropical climate, the high air temperature and relative humidity values (especially during the summer) decrease production performance, and are the main factors affecting the breeding of birds. Considering the potential increase in poultry meat consumption in the world and its effects on the economy globalization, the Brazilian poultry industry has been looking for the optimal bind density to become more competitive. Larger number of birds housed by building area, on the other hand, results in larger heat production, which needs to be dissipated. Therefore, it is indispensable to improve the artificial thermal conditioning systems for the breeding of broiler chickens or laying hens in high density to be viable for the conditions of the Brazilian tropical climate. As a consequence, attention to the suitable design of the poultry facilities has become a priority.

The advances in the geographic information systems (SIG), and the greater availability of the meteorological data, permit that systems of artificial conditioning of the environment according to the climatic conditions of each region can be studied. The simulations of the poultry housing thermal behavior with and without Adiabatic Evaporative Cooling (SRAE) allow the decision makers to evaluate the economical viability and the installation costs of a poultry production business. For this research objective place, the first step was to carry out the thermal behavior model test developed by Gates et al. (1995) for chicken sheds in the United States, based on the hypothesis that this model, using climatized sheds, as proposed by the authors, could be used under Brazilian conditions.

\section{MATERIALS AND METHODS}

The proposed model uses relative temperature and humidity climatic data, the estimated production of latent heat and sensibility of the housing chicken, the mass air flow, and the efficiency of the adiabatic cooling system for the calculation of the dry bulb temperature and the humidity inside the housing.

The equations according to Gates et al. (1995) for the housing without evaporating adiabatic cooling are the following:

$$
\begin{gathered}
\mathrm{t}_{\mathrm{d}, \mathrm{bs}}=\mathrm{t}_{\mathrm{f}, \mathrm{bs}}+\frac{\mathrm{q}_{\mathrm{s}} \mathrm{n}_{\mathrm{a}} \mathrm{m}_{\mathrm{a}}}{\mathrm{m} \mathrm{c}_{\mathrm{p}}} \\
\mathrm{UE}_{\mathrm{d}}=\mathrm{UE}_{\mathrm{f}}+\frac{\mathrm{q}_{\mathrm{L}} \mathrm{n}_{\mathrm{a}} \mathrm{m}_{\mathrm{a}}}{\dot{\mathrm{m} h}_{\mathrm{fg}}}
\end{gathered}
$$

For the housing with the evaporative adiabatic cooling system, the heat taken out from the air by the system and the added water vapor is also considered, as shown in the equations below:

$$
\mathrm{t}_{\mathrm{d}, \mathrm{bs}}=\mathrm{t}_{\mathrm{f}, \mathrm{bs}}+\frac{\mathrm{q}_{\mathrm{s}} \mathrm{n}_{\mathrm{a}} \mathrm{m}_{\mathrm{a}}-\beta \dot{\mathrm{m}}_{\mathrm{w}} \mathrm{h}_{\mathrm{fg}}}{\dot{\mathrm{m}} \mathrm{c}_{\mathrm{p}}}
$$

$$
\mathrm{UE}_{\mathrm{d}}=\mathrm{UE}_{\mathrm{f}}+\frac{\mathrm{q}_{\mathrm{L}} \mathrm{n}_{\mathrm{a}} \mathrm{m}_{\mathrm{a}}+\beta \dot{\mathrm{m}}_{\mathrm{w}} \mathrm{h}_{\mathrm{fg}}}{\dot{\mathrm{m}}_{\mathrm{fg}}}
$$

Where:

$t_{d, b s}$ - Dried bulb temperature inside the poultry house, ${ }^{\circ} \mathrm{C}$

$\mathrm{t}_{\mathrm{f}, \mathrm{bs}}$ - Dried bulb temperature outside the poultry house, ${ }^{\circ} \mathrm{C}$

$\mathrm{q}_{\mathrm{s}}$ - Sensible heat produced, $\mathrm{W} \mathrm{kg}^{-1}$ of live animal mass

$\mathrm{q}_{\mathrm{r}}$ - Latent heat produced, $\mathrm{W} \mathrm{kg}^{-1}$ of live animal mass

$\mathrm{n}_{\mathrm{a}}$ - Number of broilers

$\mathrm{m}_{\mathrm{a}}$ - Mass per broiler, kg of the live animal

$\dot{\mathrm{m}}_{\mathrm{w}}$ - Mass water flow, water $\mathrm{kg} \mathrm{s}^{-1}$

$\dot{\mathrm{m}}$ - Mass air flow, air $\mathrm{kg} \mathrm{s}^{-1}$

$\beta$ - Evaporated vapor fraction

$\mathrm{C}_{\mathrm{p}}$ - Air specific heat, $\mathrm{J} \mathrm{kg}^{-1}{ }^{\circ} \mathrm{C}^{-1}$

$\mathrm{UE}_{\mathrm{d}}$ - Specific air humidity inside the poultry house, water vapor $\mathrm{kg}$ air $\mathrm{kg}^{-1}$

$\mathrm{UE}_{\mathrm{f}}$ - Specific air humidity outside the poultry house, water vapor $\mathrm{kg}$ air $\mathrm{kg}^{-1}$

$\mathrm{h}_{\mathrm{fg}}$ - Latent heat of the air vaporizing, $\mathrm{J} \mathrm{kg}^{-1}$, using $2,43 \times 10^{6} \mathrm{j} \mathrm{kg}^{-1}$

The following initial assumptions were adopted: the sensible heat production to the chicken is uniform and constant; the latent heat produced by the chicken is uniform and constant; sensible heat gained by mechanical, electrical and other sources, such as motor and lights are negligible; the sensible heat resulting from the absorption of solar irradiation in the interior of the installation is negligible; the sensible heat transferred through the building construction, such as roof, walls, doors, etc, are negligible, the heat transferred to the floor through the region near the building perimeter is negligible; the mass air flow is constant, and the cooling system works in a uniform and constant way.

The poultry houses studied for the model validation belong to a commercial farm in the Palotina city, Paraná state latitude $24^{\circ} 17^{\prime} \mathrm{S}$, longitude $53^{\circ} 50^{\prime}$ W' a $233 \mathrm{~m}$ altitude. This farm adopts the climatized model poultry house, composed of a negative ventilation system. This system has been adopted by the Brazilian chicken industry, especially in the high density productions. In Table 1 the building characteristics of the poultry house are defined and animal variables used in the model validation.

The environmental data were obtained from January to February 2002 during a three-week period (Silva, 2002), with chicken from 21 day-old up to 42 day-old (2.45 kg). Every two hours, data from the dry bulb temperature, wet bulb temperature, the black globe temperature and the air velocity inside and outside the housing were recorded. Inside the poultry house, the sensors were installed at $0.30 \mathrm{~m}$ (corresponding to the chicken central mass) and at $1.10 \mathrm{~m}$ from the floor, being set, for each height, three uniformly distributed sensors.

The sensors used inside the poultry house were the temperature and humidity sensors (Incoterm model hld5203) and 
Table 1. Building characteristics of two the poultry houses and animal variables used in the model validation (Silva, 2002)

\begin{tabular}{|c|c|}
\hline Broiler number & 21600 broilers \\
\hline Broiler mass & $2.45 \mathrm{~kg}$, in average \\
\hline Broiler age & 7 weeks \\
\hline Mass Airflow & $\begin{array}{l}82.4 \mathrm{~kg} \text { of air per second (expanded clay) } \\
120.8 \mathrm{~kg} \text { of air per second (cellulose) }\end{array}$ \\
\hline \multicolumn{2}{|c|}{ Poultry House Dimensions } \\
\hline Length & $120 \mathrm{~m}$ \\
\hline Width & $12 \mathrm{~m}$ \\
\hline Height & $2,5 \mathrm{~m}$ \\
\hline Animal density & 15 chicken per $\mathrm{m}^{2}$ \\
\hline Exhauster fans & 10 units, being 4 at the back and 3 in each side wall \\
\hline Evaporative Pad & $\begin{array}{l}\text { expanded clay (first poultry house) } \\
\text { cellulose (second poultry house) }\end{array}$ \\
\hline Efficiency & $\begin{array}{l}53 \% \text { - in expanded clay } \\
68 \% \text { - in cellulose }\end{array}$ \\
\hline
\end{tabular}

a rotational anemometer with a $0.1 \mathrm{~m} \mathrm{~s}^{-1}$ resolution. Outside the installation, a meteorological station composed of a maximum and minimum thermometer, a temperature and humidity sensors (Incoterm model hld5203) and a rotational anemometer. The readings were done at the same time and period as those inside the poultry house.

The psychrometric variables were calculated through routines developed in the $\mathrm{C}$ programming language by Zhang \& Gates (2004), being, however, converted to the FORTRAN 95 language. The humid bulb temperature calculation is done, in these routines, using the successive interactions (Zhang et al., 1997).

To calculate the latent and sensible heat production by the chicken an equation developed by Pedersen \& Thomsen (2000) was used, as given below:

$$
\begin{aligned}
& \mathrm{q}_{\mathrm{t}}=9.84 \mathrm{~m}_{\mathrm{a}}^{0,75}\left(4 \cdot 10^{-5}\left(20-\mathrm{t}_{\mathrm{bs}}\right)^{3}+1\right) \\
& \mathrm{q}_{\mathrm{s}}=0.83 \mathrm{q}_{\mathrm{t}}\left(0.8-1.85 \cdot 10^{-7}\left(\mathrm{t}_{\mathrm{bs}}+10\right)^{4}\right)
\end{aligned}
$$

Where:

$$
\begin{gathered}
\mathrm{q}_{\mathrm{t}}-\text { Total heat production, } \mathrm{J} \mathrm{s}^{-1} \\
\mathrm{q}_{\mathrm{s}}-\text { Sensible heat produced, } \mathrm{J} \mathrm{s}^{-1} \\
\mathrm{~m}_{\mathrm{a}}-\text { mass per animal, live animal kg } \\
\mathrm{t}_{\mathrm{ts}}-\text { Dry bulb temperature, }{ }^{\circ} \mathrm{C}
\end{gathered}
$$

Comparisons with the model starting data were made, from the data of the dry bulb temperature and relative humidity inside the poultry houses, whose entry data collected in the poultry house were used. The standard error was calculated according to the one described by Spiegel (1977).

In the Model validation, due to the need of knowing the latent and sensible heat generated by broilers, it was necessary to adjust an equation to determine the chicken daily body mass. This determination was done based on the experimental data of the weight gain of 60 selected chickens, comprising their whole growing period. To improve the sample process, the selected broilers were divided in groups of 20 animals comprising three distinct sections in the poultry house. The body mass determination was done weekly.

\section{RESULTS AND DISCUSSION}

In each poultry house there were two temperature and humidity sensors positioned at one meter from the porous material in opposite sides of the poultry house to determine the cooling and evaporative adiabatic system efficiency. The variation among the values obtained by the sensors is due to the instrument precision and to random factors. In other words, in an ideal situation they would indicate the same values. The difference between them was used as an indicative of an acceptable error for the model. The difference between the two sensors, calculated in the same way that the standard error for the temperature values, was $0.95^{\circ} \mathrm{C}$.

The plotting of the values for the temperature obtained in the poultry house with cellulose evaporative panels and the ones estimated by the model visually shows the good results of the model (Figure 1A).

This is confirmed by the calculus of the standard error for the temperature values, which was $0.89^{\circ} \mathrm{C}$. This is inferior to the one calculated between two sensors inside the poultry house described above. Similarly, for absolute humidity, the difference between the two sensors inside the poultry house described above was calculated in the same way as the standard error for the specific humidity values. The value of 0.001 water $\mathrm{kg}$ air $\mathrm{kg}^{-1}$ was obtained.

The plotting of the specific humidity values obtained in the poultry house with cellulose evaporative panels and the ones estimated by the model also show visually the good result of the model (Figure $1 \mathrm{~B}$ ).

Also confirmed was the standard error calculus for the humidity values, which was 0.000846 water $\mathrm{kg}$ air $\mathrm{kg}^{-1}$. The error is also inferior to the one calculated between the two sensors inside the poultry house described above.

It is worth pointing out that the dry temperature and absolute humidity values inside the poultry house are the average of six sensors, which in theory results in a more representative value obtained. If the model is a good one, the standard error will be smaller, which can explain the values smaller than the error between the sensors inside the poultry house.

It is also interesting to note that elements not considered in the model may have a higher effect upon the black globe temperature than upon the dry bulb temperature.

For the poultry house using expanded clay as the porous material the result, in the absolute humidity case, is good as can be seen in Figure 1C, having a standard error of 0.0014 water $\mathrm{kg}$ air $\mathrm{kg}^{-1}$.

As for the temperature, the results did not show a good adaptation, with a standard error of $2.25^{\circ} \mathrm{C}$. But the values given by the model show a good tracking of the real values variations, as can be seen in Figure 1D.

The model neglects a series of heat sources. The heat source from the roof is the most important component for 
A.

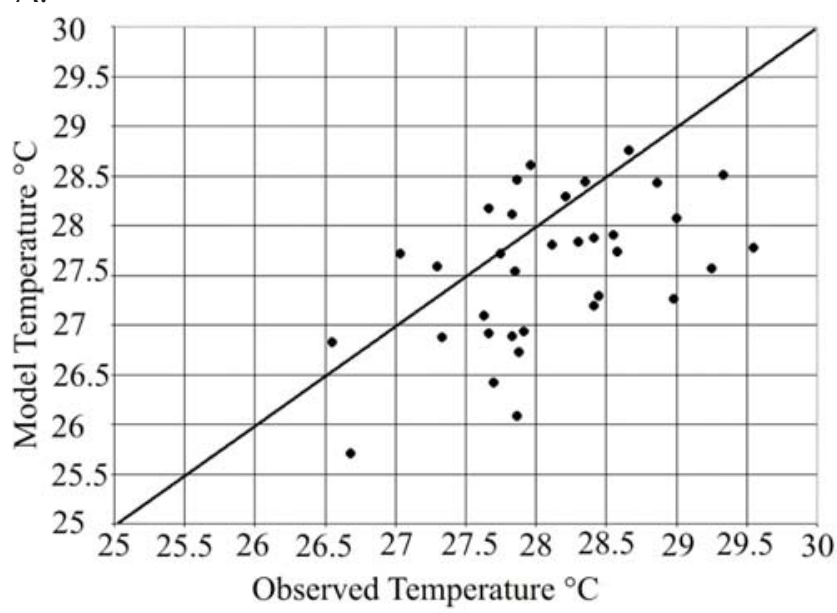

C.

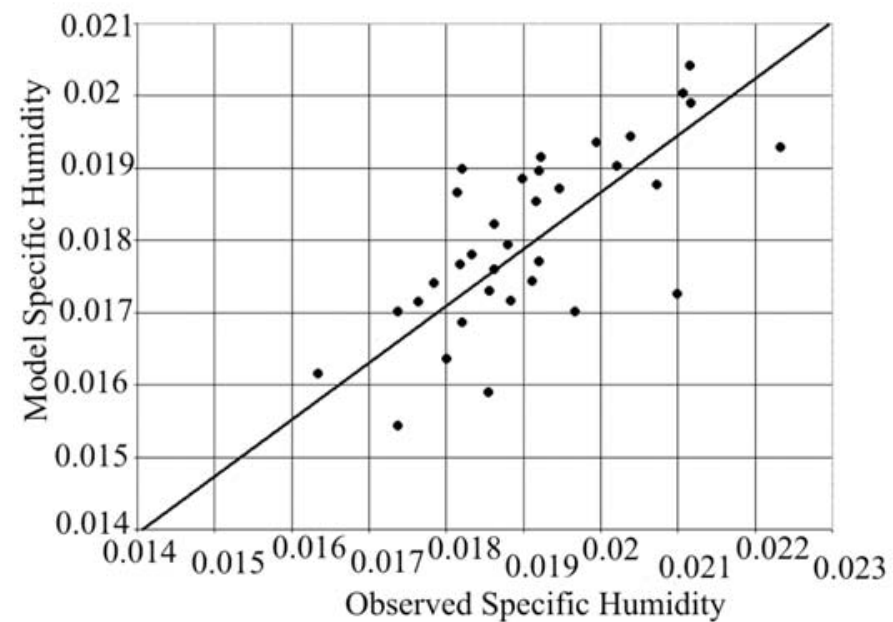

B.

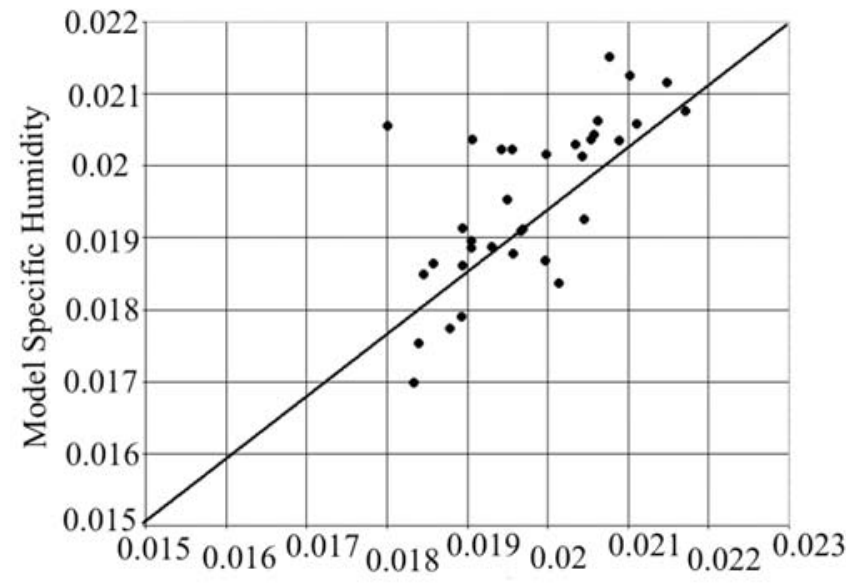

Observed Specific Humidity

D.

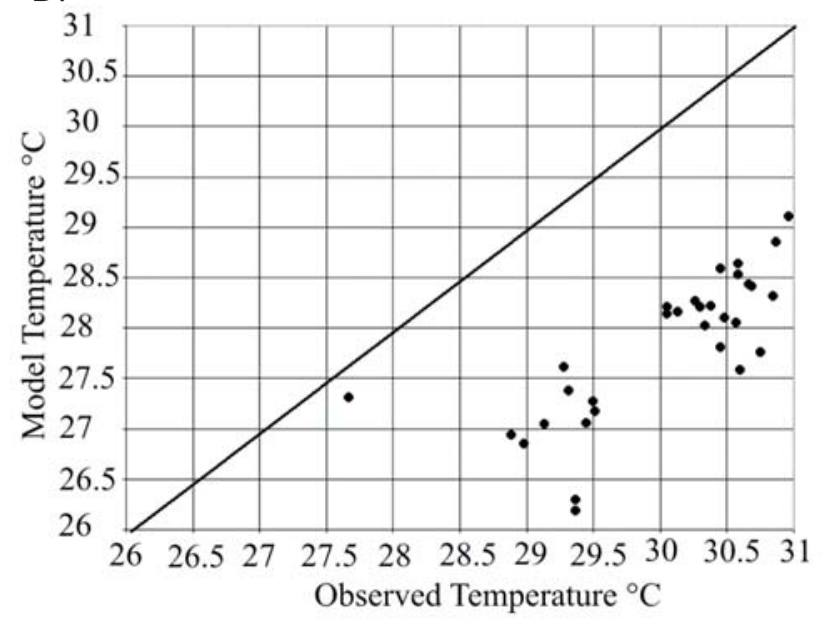

E.

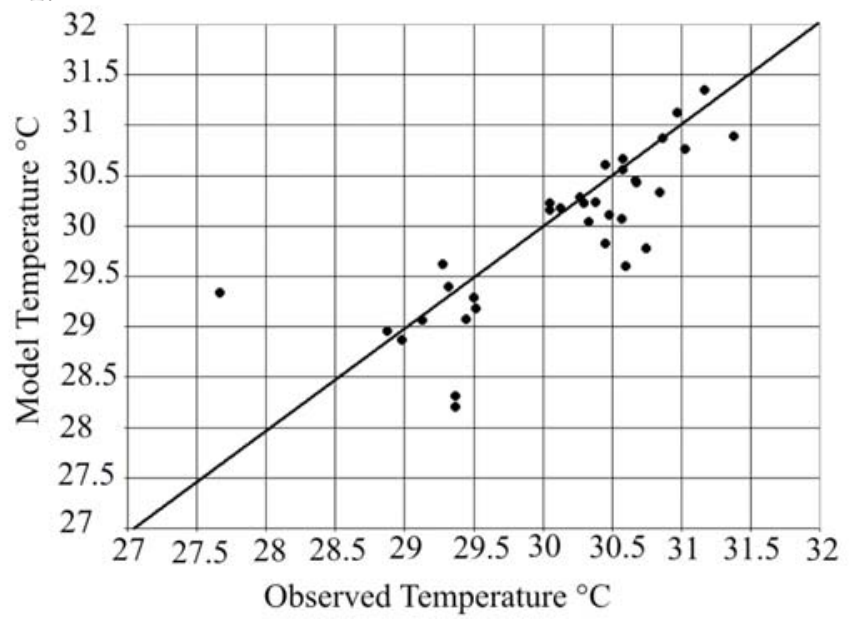

Figure 1. A. Values of the temperature inside the poultry house using cellulose evaporative pads compared to those estimated by the model. B. Specific humidity values inside the poultry house using cellulose evaporative pads compared to those estimated by the model. C. Specific humidity values inside the poultry house equipped with evaporative pads in expanded clay compared to the ones estimated by the models. D. Temperature values inside the poultry house equipped with expanded clay evaporative pads compared to the ones estimated by the model. E. Temperature values inside the poultry house equipped with expanded clay evaporative Pads compared to the ones estimated by the model using a correction factor

the building being considered, which is typical in many broiler production systems in Brazil. In contrast, the roofs of USA poultry houses are thermically isolated. Adding a $\Delta$ correction factor to the equation relative to the heat not accounted by the model in the original form that calculates the dry bulb temperature, results in:

$$
\mathrm{t}_{\mathrm{d}, \mathrm{bs}}=\mathrm{t}_{\mathrm{f}, \mathrm{bs}}+\frac{\mathrm{q}_{\mathrm{s}} \mathrm{n}_{\mathrm{a}} \mathrm{m}_{\mathrm{a}}+\Delta-\beta \dot{\mathrm{m}}_{\mathrm{w}} \mathrm{h}_{\mathrm{fg}}}{\dot{\mathrm{m}}_{\mathrm{p}}}
$$


$\Delta$ - correction factor referring heat sources from the roof and wall, $\mathrm{J} \mathrm{s}^{-1}$

We obtained a $\Delta$ of $167000 \mathrm{~J} \mathrm{~s}^{-1}$ by adjusting a value for $\Delta$ by consecutive approximations. Applying the new equation, the standard error reduced to $0.52{ }^{\circ} \mathrm{C}$, as shown in Figure 1E.

\section{CONCLUSIONS}

1. The model is suitable for the proposed objective in the form proposed by Gates et al. (1995) for poultry houses with elevated mass air flow rate (120.8 air kg air s${ }^{-1}$ or higher).

2. A correction factor referring to a series of heat sources not include in the model, or the inclusion of these sources, is necessary for poultry houses without a an elevated mass air flow.

3. Elevated mass air flow into the building may have a stronger effect on the air temperature as compared to the black globe temperature because the present model does not account for radiation effects, such as infrared radiation from the roof.

\section{LITERATURE CITAD}

Gates, R. S.; Zhang, S. H.; Colliver, D. G.; Overthults, D. G. Regional Variation in temperature humidity index for poultry housing. Transactions of the Asae, v.38, n.1, p.197-205, 1995.

Pedersen, S.; Thomsen, M. G. Heat and moisture production of broilers kept on straw bedding. Journal of Agricultural Engineering Research, Silsoe, Bedford, UK, v.75, p.177187, 2000.

Silva, C. E. da.; Comparação de painéis evaporativos de argila expandida e celulose para sistema de resfriamento adiabático evaporativo do ar em galpões avícolas com pressão negativa em modo túnel. Viçosa: UFV, 2002. p.67. Dissertação Mestrado

Spiegel, M. R. Estatística. São Paulo: McGraw-Hill, 1977. 580p. Zhang, H.; Gates, R. S. Psychrometric computing and source code generators, http://www.bae.uky.edu/gates/psych/psych.htm. 10 Out. 2004.

Zhang, H.; Gates, R. S.; Colliver, D. G.Turing machine approach to solve psychrometric attributes. Transactions of the ASAE, St. Joseph, MI , v.40, n.3, p823-831. 1997. 